\title{
Multiple Auer Rods in Fine-Needle Aspiration Smears of Medullary Thyroid Carcinoma: An Unusual Finding
}

This article was published in the following Dove Press journal: International Medical Case Reports Journal

\section{Maryam Mohammadnia Avval (D) \\ Perikala Vijayananda Kumar Fereydoon Dehghani}

Department of Pathology, Shiraz University of Medical Sciences, Shiraz, Iran
Background: Medullary thyroid carcinoma (MTC) is a rare tumor. Fine-needle aspiration (FNA) cytology is a popular method for the preoperative diagnosis of MTC.

Case Report: A 45-year-old man was referred to our center for a palpable thyroid nodule. Ultrasound-guided FNA was carried out for the patient. Cytology slides showed many isolated and small clusters of round to oval cells, some with a moderate amount of cytoplasm and red cytoplasmic granules. Rare cells showed multiple red Auer rods. Histology confirmed the diagnosis of MTC.

Conclusion: Cytologic findings of MTC in FNA are variable, and several rare cytologic findings have been reported. Cytoplasmic red granules are one of the usual findings, whereas detection of cells containing multiple Auer rods is an unusual finding, which has not been reported so far.

Keywords: medullary thyroid carcinoma, fine-needle aspiration, cytoplasmic multiple Auer rods

\section{Introduction}

Medullary thyroid carcinoma (MTC) is a rare neoplasm of thyroid. Accurate preoperative diagnosis of this tumor is important for proper clinical management. Patients with multiple endocrine neoplasia type 2 (MEN-2) may present with both MTC and pheochromocytoma. These patients need to undergo adrenalectomy before thyroidectomy. Also, preoperative measurement of calcitonin and carcinoembryonic antigen (CEA) is necessary for future follow-up of patients with MTC. ${ }^{1}$

Fine-needle aspiration (FNA) is a popular method for preoperative diagnosis of thyroid neoplasms. Cytologic criteria of MTC in FNA have been well established in previous studies. ${ }^{2-5}$ Also, many unusual findings have been reported in patients with MTC. ${ }^{6-10}$ In our case, we report cells with multiple Auer rods, which have not been reported before.

\section{Case Report}

A 45-year-old man presented with a palpable thyroid nodule. Ultrasonography showed a partially ill-defined hypoechoic nodule, measuring $29 \times 20 \mathrm{~mm}$ in the right lobe. Ultrasound-guided FNA was carried out, and four smears were prepared. Two slides were air-dried and stained with the Wright method, and two slides were alcohol-fixed and stained using the Papanicolaou method.

\footnotetext{
Correspondence: Maryam Mohammadnia Avval

Department of Pathology, Shiraz

University of Medical Sciences,

KarimkhanZand Street, Shiraz

7I34845794, Iran

Tel +989 I 55129932

Email m_mohammadnia@sums.ac.ir
} 
In the microscopic evaluation, hypercellular smears were arranged in dissociated cells and small cohesive clusters. Most cells had round to oval shapes, and many of them contained eccentric nuclei. Anisonucleosis, multinucleation, and some bizarre cells were also observed. Rare intranuclear cytoplasmic inclusions were present. Many cells contained a moderate amount of cytoplasm, and some cells contained red granules. In the background, small foci of pink materials resembling amyloid were present (Figure 1). In the cytoplasm of rare cells, multiple eosinophilic rods resembling Auer rods of neoplastic myeloblasts were also detected (Figure 2).

Diagnosis of MTC based on FNA was established. However, granulocytic sarcoma was in differential diagnosis. The patient did not have a history of myeloid neoplasm; also, bone marrow and peripheral blood were normal. He underwent total thyroidectomy. Pathology sections showed a neoplastic lesion composed of sheets of round cells with stippled
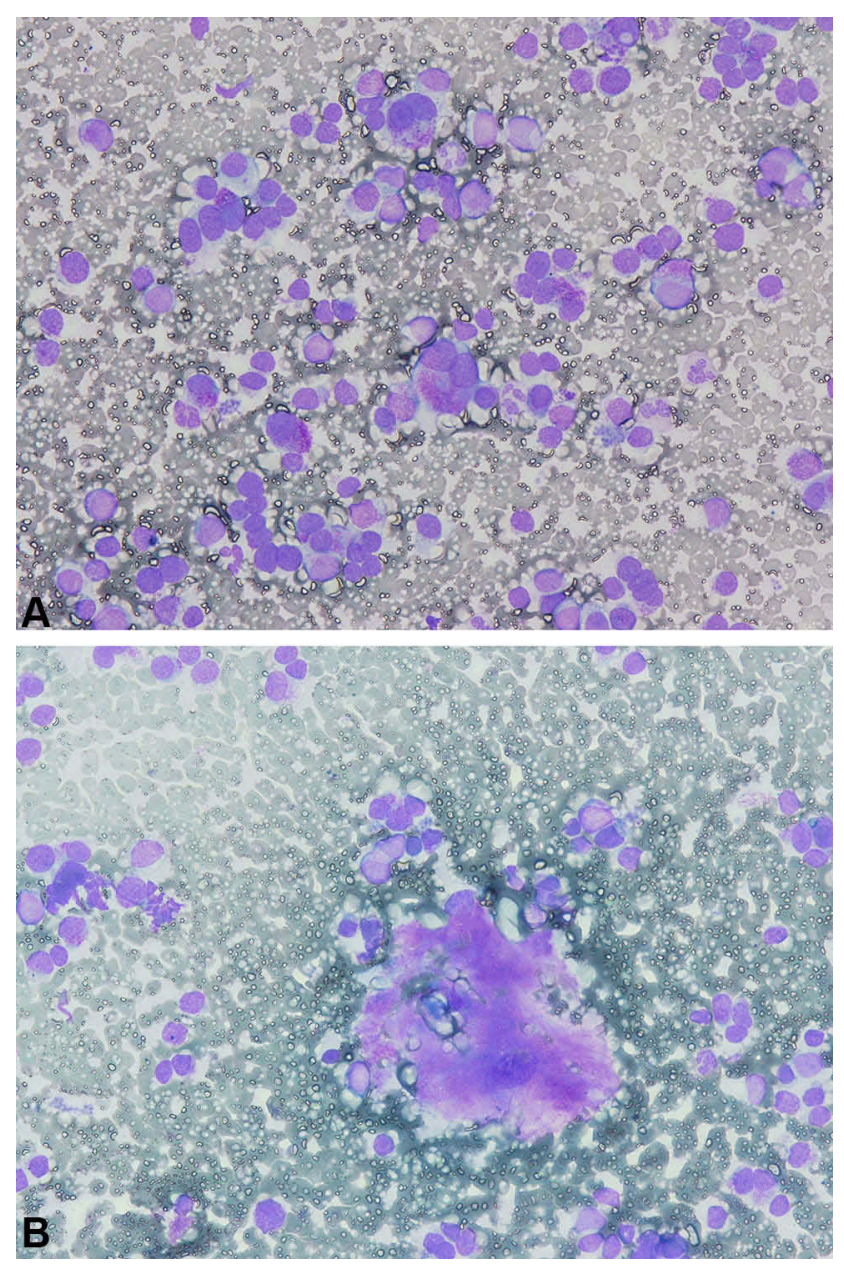

Figure I Cytologic smears. (A) Isolated mononucleated and binucleated cells, some with cytoplasmic granules (Wright stain, $\times 400$ ). (B) Amyloid-like materials (Wright stain, $\times 400)$.
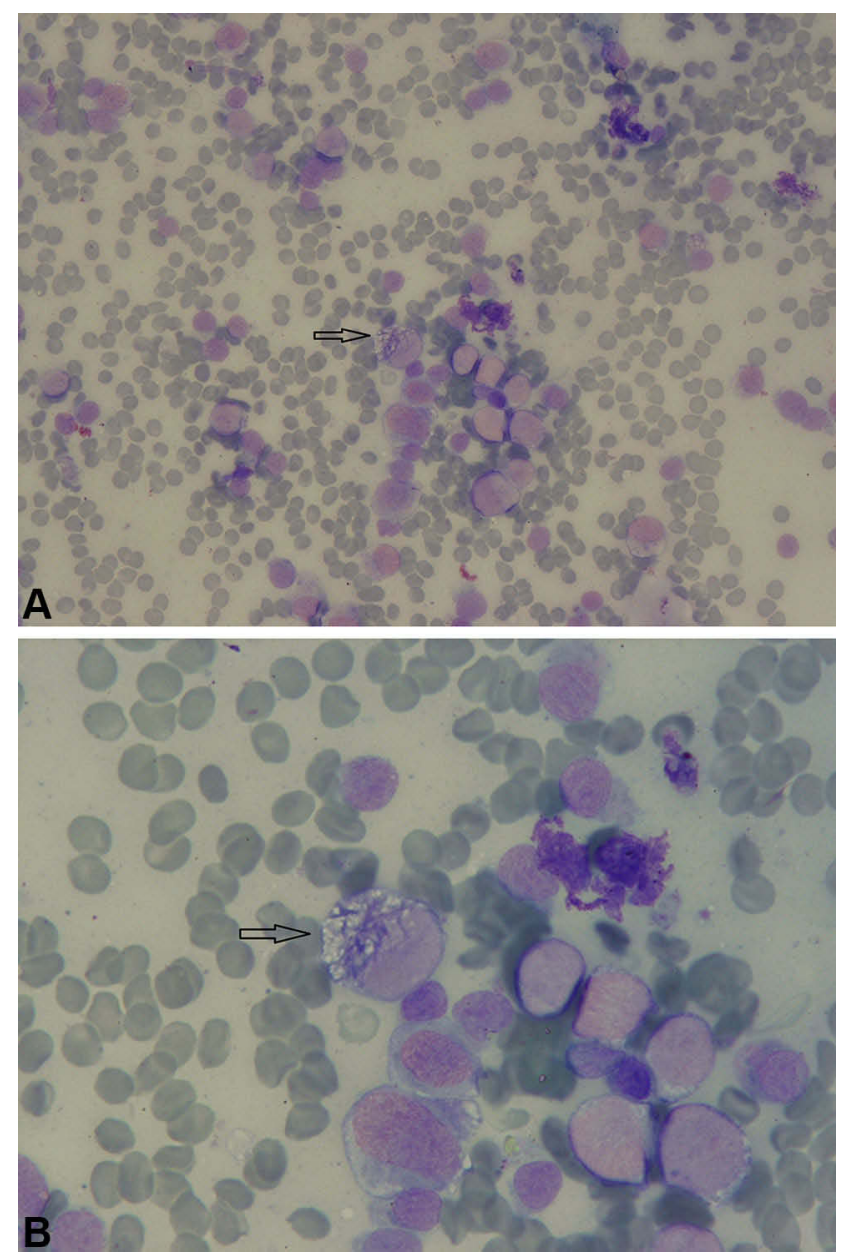

Figure 2 Cytologic smears. (A and B) Round cells with multiple Auer rods in the cytoplasm (arrow) (A, Wright stain, $\times 400$ and B, Wright stain, $\times 1000$ ).

chromatin and amyloid deposition (Figure 3). Congo red staining confirmed amyloid materials. Also, Immunohistochemical staining was done. Calcitonin and thyroid transcription factor 1 (TTF-1) were positive and thyroglobulin was negative. Accordingly, final diagnosis of MTC was confirmed.

\section{Discussion}

MTC is identified as a rare thyroid neoplasm. Accurate preoperative diagnosis of MTC is important for proper management. Until now, several studies have been carried out regarding the cytologic features of MTC in FNA cytology. According to these studies, there is extensive variability in cytologic findings; therefore, MTC may be misdiagnosed as other neoplasms. ${ }^{3,4}$ In addition, some unusual findings have been reported. ${ }^{6-10}$ In this regard, Kaushal et al evaluated thyroid FNA of 78 MTC cases and reported unusual findings, such as melanin pigments, vacuolated cytoplasm, intracytoplasmic lumina, and signet ring cells in rare cases. ${ }^{6}$ 


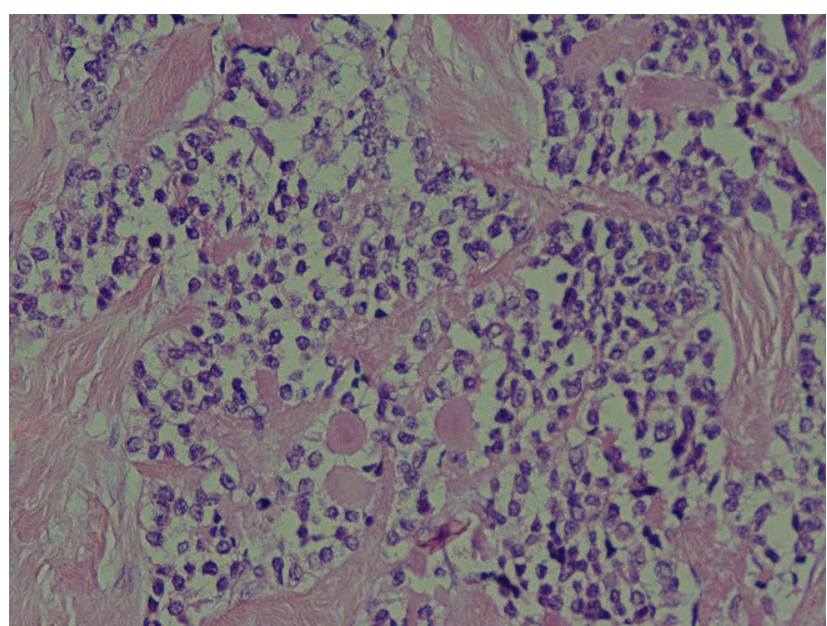

Figure 3 Histologic section. Sheets of neoplastic cells with stippled chromatin and amyloid deposition (H\&E stain, $\times 400)$.

Eosinophilic cytoplasmic granule is a well-known feature of MTC on FNA cytology. Many studies have reported these granules. ${ }^{2-4,6}$ In the present case, we found cells containing multiple red Auer rods resembling neoplastic myeloblasts. It was speculated that binding of granules produces these rods.

Rare cases of granulocytic sarcoma in thyroid have been reported but multiple Auer rods were not detected in these cases. ${ }^{11,12}$

It should be noted that cytologic features of FNA smears, including discohesive cells and small clusters, round to oval nuclei with mild to moderate pleomorphism, binucleation, intranuclear cytoplasmic inclusions, cytoplasmic red granules, and amyloid-like materials, lead us to the diagnosis of medullary carcinoma.

It can be concluded that cells with multiple Auer rods are rarely seen in MTC, and these cells should not be confused with neoplastic myeloblasts in granulocytic sarcoma.

\section{Ethics}

The patient has given his written informed consent to publish this work. Institutional approval was not required.

\section{Acknowledgment}

We would like to thank our colleagues in the Pathology Department of Shiraz University of Medical Sciences for their assistance.

\section{Funding}

This study had no grants or funding sources.

\section{Disclosure}

The authors have no conflicts of interest to declare.

\section{References}

1. Kim BH, Kim IJ. Recent updates on the management of medullary thyroid carcinoma. Endocrinol Metab (Seoul). 2016;31(3):392-399. doi:10.3803/EnM.2016.31.3.392

2. Green I, Ali SZ, Allen EA, Zakowski MF. A spectrum of cytomorphologic variations in medullary thyroid carcinoma. Fine-needle aspiration findings in 19 cases. Cancer. 1997;81(1):40-44. doi:10.1002/(ISSN)1097-0142

3. Jaiswal S, Prasad R, Siddiqui F, et al. Cytomorphological features of medullary thyroid carcinoma: an analysis based on 41 ultrasound-guided fine-needle aspiration specimens. World $J$ Endocr Surg. 2018;10(2):108-118. doi:10.5005/jp-journals-100 02-1229

4. Papaparaskeva K, Nagel H, Droese M. Cytologic diagnosis of medullary carcinoma of the thyroid gland. Diagn Cytopathol. 2000;22 (6):351-358. doi:10.1002/(ISSN)1097-0339

5. Mehdi G, Maheshwari V, Ansari HA, Sadaf L, Khan MA. FNAC diagnosis of medullary carcinoma thyroid: a report of three cases with review of literature. J Cytol. 2010;27(2):66-68. doi:10.4103/ 0970-9371.70745

6. Kaushal S, Iyer VK, Mathur SR, Ray R. Fine needle aspiration cytology of medullary carcinoma of the thyroid with a focus on rare variants: a review of 78 cases. Cytopathology. 2011;22 (2):95-105. doi:10.1111/cyt.2011.22.issue-2

7. Kumar PV, Hodjati H, Monabati A, Talei A. Medullary thyroid carcinoma. Rare cytologic findings. Acta Cytol. 2000;44 (2):181-184. doi:10.1159/000326358

8. Sams SB, Tompkins KD, Mayson S, Raeburn CD, Mehrotra S. Oncocytic variant of medullary thyroid carcinoma; a rare tumor with numerous diagnostic mimics by fine needle aspiration. Diagn Cytopathol. 2017;45(12):1148-1152. doi:10.1002/dc.23790

9. De Lima MA, Dias Medeiros J, Rodrigues Da Cunha L, et al. Cytological aspects of melanotic variant of medullary thyroid carcinoma. Diagn Cytopathol. 2001;24(3):206-208. doi:10.1002/ 1097-0339(200103)24:3<206::AID-DC1042>3.0.CO;2-H

10. Tong GX, Hamele-bena D, Wei XJ, O'toole K. Fine-needle aspiration biopsy of monophasic variant of spindle epithelial tumor with thymus-like differentiation of the thyroid: report of one case and review of the literature. Diagn Cytopathol. 2007;35(2):113-119. doi:10.1002/dc.20579

11. Goldenberg D, Joshi M, Malysz J, Claxton D, Cottrill EE. Myeloid sarcoma of the thyroid. Ear Nose Throat J. 2017;96(12):460-461. doi:10.1177/014556131709601205

12. Khanna G, Damle NA, Agarwal S, et al. Mixed phenotypic acute leukemia (mixed myeloid/B-cell) with myeloid sarcoma of the thyroid gland: a rare entity with rarer association - Detected on FDG PET/CT. Indian J Nucl Med. 2017;32(1):46-49. doi:10.4103/09723919.198478 


\section{Publish your work in this journal}

The International Medical Case Reports Journal is an international, peer-reviewed open-access journal publishing original case reports from all medical specialties. Previously unpublished medical posters are also accepted relating to any area of clinical or preclinical science. Submissions should not normally exceed 2,000 words or 4

published pages including figures, diagrams and references. The manuscript management system is completely online and includes a very quick and fair peer-review system, which is all easy to use. Visit http://www.dovepress.com/testimonials.php to read real quotes from published authors. 